\title{
The Viability Of English Television Programs Inside Of South Korean Classrooms
}

\author{
Scott Wayne Kines, Hankuk University of Foreign Studies, South Korea
}

\begin{abstract}
English television programs have been incorporated within public-school classrooms in western countries for a long time to capture student interest in various subjects. Many researchers favor English programs as a partner inside of classrooms while others hold negative perceptions of the concept. However, there is little research to provide a better understanding of how English television programs have been accepted within South Korean public-school EFL classrooms by teachers and public administrative professionals. Since South Korea's Ministry of Education is aggressively identifying alternative ways to reduce household spending on private English education, this study attempts to determine if English television programs can be a viable partner in South Korean EFL classrooms. Fifty public-school EFL teachers covering schools in Seoul, Bucheon, Suwon, and Incheon were surveyed to provide better insight. A majority of the participants indicated they instruct their students to watch English programs as a part of their lesson plans, but this study also indicates the strategy has been applied sparingly.
\end{abstract}

Keywords: EFL (English as a foreign language); Private Education; Ministry of Education; Public School; English Television Programs

\section{CHAPTER ONE: INTRODUCTION}

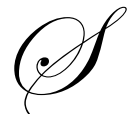

outh Koreans are known to be the most passionate people in the world when it comes to education (Rhie, 2002). Since South Korea lacks natural resources, its people are challenged to pursue higher education as a medium to boost the country's economy. Many would argue the strategy has paid off (Rhie, 2002). English education in particular plays a substantial role within Korean society. In fact, several top universities allocate a lot of weight to the English component of Korea's entrance examination so students at all levels attend after-school programs to gain a competitive edge. However, the Korean Ministry of Education is looking for ways to lessen Korea's reliance on private after-school programs. With regards to English education, Huh (2002) stated the current educational system in South Korea has yet to prepare one to become equipped neither with the necessary language capabilities nor with intercultural understandings for globalized English communication.

According to Howard Gardner's Theory of Multiple Intelligences, every learner has his or her own unique intelligence and way of taking in new information (Johnson, 2005). As a result, educators have to be sure to develop lesson plans which cater to diverse student needs. For example, some of us have oral intelligence, while others may be visual, spatial, logical, and so on. Television is just one of many resources which could be used to galvanize a diversified classroom of multiple intelligences. Furthermore, an earlier research study (Kines, 2010) indicated that English television programs have positively impacted the speaking abilities of a majority of South Korean EFL (English as a foreign language) students who were surveyed. However, within America, television has been blamed for lowering Scholastic Aptitude Test (SAT) scores and increased violence among children. Moreover, others feel that television has no place inside of a classroom because the viewing process dissuades active participation and leads to a mindless waste of time. Whether English television programs have a place in South Korean public school classrooms is a matter of question since its educational environment overall is largely exam driven. 
Chapter one will present an overview of the study by introducing the background, purpose, significance, limitations and delimitations of the study.

\section{Background to the Study}

Television has been utilized within western classrooms for a number of years. Some research suggests that television in general stimulates valuable discussions resulting from emotional responses (Ryan, 2003) while others insist that television within a classroom can only trigger a mindless activity with little if any benefit to students. Now, let us journey over to South Korea where exam stress in public schools is high, especially with regards to English. In light of Korea's high demand for English competence from its students, Korea's Ministry of Education has been looking for solutions to curb household spending on private education since its English educational system seems to lack in producing speaking competence among students (Rhie, 2002). This study hopes to discover whether or not English television programs have been embraced to some degree within public- EFL classrooms in South Korea.

\section{Purpose of the Study}

The purpose of this study is to review the viability of English television programs as a partner in South Korean EFL classrooms.

\section{Personal Statement}

As an EFL teacher with over five years of experience in South Korea, I have had the opportunity to discuss language-learning strategies with many professionals within the industry and students alike. Last year I presented a study about the impact of English television programs on students since many of my own students with perceived English-speaking competence had credited watching these programs as the primary source to boosting their skills. Last year's quantitative study targeted university students while this year's study surveys public-school EFL teachers instead. I should admit that I have fully embraced English television programs as a resource in my own classrooms based on conversations and feedback with and from my students coupled with the results of my previous study where a large percent of participants, who had routinely watched seven or more hours of English television programs per month, indicated their English-speaking skills were positively impacted by the viewing process. I wanted to extend my previous study by surveying actual South Korean public-school EFL teachers for this study as a way to compliment my previous study where only students were invited to participate.

\section{Research Questions}

Based on the purpose of this research study, the following questions guide my research:

- $\quad$ Are a majority of public-school EFL teachers in South Korea already using English television programs inside their classrooms?

- If so, how often, how, and why are they using English programs to compliment EFL learning?

- $\quad$ For those EFL teachers who are not currently using English programs as a lesson compliment, why not?

- $\quad$ For those teachers already using English programming, what impact have these programs had on their students' English speaking ability?

\section{Significance of the Study}

This study should provide insight for public-school EFL teachers in South Korea of the potential value English programs may add to their lesson plans. Also, this study strives to shed light on various methods EFL teachers are already assimilating within their classrooms as they use English programs. Hopefully, this research will provide a stepping stone for further investigation into whether or not the Korean Ministry of Education should mandate the strategy into all public schools, or at least test market the concept within some school districts. The findings may have implications for the students, their parents, and any potential funding policy for English programming within public-school districts. 


\section{Assumptions}

Since this is a quantitative study, assumptions have to be made. Assumptions important to carrying out this study include the following:

- $\quad$ The participants in this study answered the survey questions honestly.

- $\quad$ The input of some participants did not impact the input of other participants.

- $\quad$ Answers to questions subjective in nature are based on potential evidence.

- $\quad$ The treatment was administered to each respondent the same way.

\section{Limitations}

Limitations identify potential weaknesses outside the control of the researcher. For this study, only a small population of fifty respondents participated in one of several provinces within South Korea so it could be argued the results of this study can not reflect the views and methods of all South Korean public-school EFL teachers. Finally, some of the questions were subjective in nature so answers to those particular questions may not be supported by evidence.

\section{Delimitations}

In order to make this study more manageable, contacts within my professional network were summoned for help. Since my professional social network solely exists within South Korea's Gyeonggi-do province and Seoul, only teachers from these two areas were summoned for participation.

As reported, The Korean Ministry of Education is looking into ways to create a better EFL teaching environment in South Korea so I solely targeted public-school EFL teachers for participation.

\section{Key-Word Definitions}

- $\quad$ Closed Captioning - A term used to describe several systems developed to display text on a television or video screen to provide additional interpretive information to viewers who wish to accept it.

- $\quad \mathbf{E F L}-$ English as a foreign language.

- $\quad$ ESL - English as a second language.

- $\quad$ Korea Ministry of Education - The central administration in Korea which oversees the process of public education from kindergarten to the third and final year of high school.

- $\quad$ Prior Knowledge - A combination of a learner's experiences, pre-existing attitudes, and knowledge base.

- Situational Comedies - Often shortened to sitcom, is a genre of comedy that features recurring characters in a common environment such as a home or workplace, accompanied with jokes as a part of the dialogue.

- $\quad$ Student Centered Classrooms - A classroom environment where students are given autonomy to fully participate within lectures by asking questions, offering opinions, or even controlling the direction of a lesson.

- $\quad$ Subtitles - The text of a dialogue translated into another language and usually printed at the bottom of a screen.

- $\quad$ Video Clip - A short clip of video, usually from a larger piece.

- $\quad$ Video Technology - Technology to include television, DVD, and video clips.

\section{Summary}

In this chapter, I have introduced South Korea's passion for English education, pros and cons of television inside of classrooms, goals of the Korean Ministry of Education, and Howard Gardner's Theory of Multiple Intelligences. In addition, I provided the background, purpose, and significance of the study. Furthermore, I included a personal statement, research questions, assumptions, limitations, delimitations and key words. 
The next chapter is a review of literature which will identify crucial research and other related information pertinent to this study.

\section{CHAPTER TWO: LITERATURE REVIEW}

The purpose of this study is to review the viability of English television programs as a partner in South Korean EFL classrooms. Won-bok Rhie (2002) believes that South Koreans are the most passionate people in the world when it comes to education. However, he also noted there is widespread dissatisfaction with the educational environment among Koreans so many parents are sending their children abroad to study in places like America, Canada, Australia, and other English-speaking countries for second-language development. In addition, many students who do not go abroad for English attend after-school English programs among others to gain a competitive edge. In year 2000, "Korean parents spent over 7 trillion won on extracurricular study fees" (Rhie, 2002, p.168). This was equal to about 31.4 percent of the government's won budget for education. Unfortunately, productivity levels have not matched investments (Rhie, 2002). "The Korean education fever, which is known as being the hottest in the world, should be rechanneled in a way that suits changing times and society. The relentless pursuit of the anachronistic goal to enter prestigious universities at all costs has paradoxically resulted in enormous money and efforts being invested by parents to only cause the deterioration of the competitiveness of their children" (Rhie, 2002 , p. 174). On the other hand, there is evidence to suggest the Korean education system is changing by incorporating English television programs within EFL lesson plans. In one study (Kines, 2010), out of four-hundred and twenty-five questionnaires, which were collected from university students in South Korea, a majority indicated they had watched English television programs within their high school classrooms during instruction. In addition, of those surveyed who had routinely watched English television programs for at least seven-hours-per month, 96\% confirmed their English skills had improved as a result, while 55\% listed either good or significant improvement. The study (Kines, 2010) hints that English television programs are used within South Korean public schools and further indicates many students have benefited as a result. However, this current study explores effective classroom strategies for English television programs as well as teacher perceptions of its usage.

\section{Perceptions of television inside of homes and classrooms}

Within American schools, television has been used for a long time as an instruction compliment. Even as far back as in 1962, Harold Wigren (1962) promoted television as a valuable resource for teaching English in America. Wigren believed television was a competent partner inside of classrooms for the following reasons: First, "Television can serve as a vehicle for transmitting many enriching opportunities for learning not otherwise available in English classes. Secondly, television can serve to stimulate critical thinking on the part of the learners. Thirdly, television can be used to motivate students to creative self-expression in a variety of ways, both oral and written. Lastly, television viewing can be a means of sharpening listening and viewing skills" (Wigren, 1962, pp. 214-217). However, Wigren also believed television was used for doing the "usual rather than the unusual, to do everyday tasks rather than the special over-and-above learning opportunities that spell the difference between commonplace and exceptional use of the medium in far too many cases" (Wigren, 1962, p. 214). In fact, "Even Vladimir Zworykin, the inventor of television, expressed his concern about its ill effects. In 1983 on his $92^{\text {nd }}$ birthday, he stated, "I didn't even dream it would be so good, but I wouldn't let my children come close to the thing" (Walker, 1995). Robert J. Walker further conveyed that television has been blamed for lowering Scholastic Aptitude Test (SAT) scores, decreasing children's reading ability, lowering youngsters nutritional values, reducing intellectual curiosity, and causing a gradual decrease in Americans' physical fitness (Walker, 1995). To counter those views, video has been enthusiastically embraced since 1980 in the field of ESL according to Carlos Ovando (2006). "Endless uses of video abound for educational purposes, including language learning, but teachers are cautioned to use it meaningfully, for authentic, cognitively-complex learning, not as a filler for passive viewing" (Ovando, 2006, pp. 11-112). Likewise, some proponents of using television programs as a means to improve overall English skills insist valuable news summaries which are a regular source can lead to meaningful classroom discussions. "The judicious, strategically programmed use of TV means that significant up-to-date moment events in history and natural science are subjects of immediate knowledge and understanding in today's classroom" (Ryan, 2003, p. 151). While some believe (Kines, 2010) using television programs would be a way to stimulate valuable discussions resulting from emotional responses, others postulate that continuous viewing of violent television programs can have a wide range of affects on children, from exhibiting fear to demonstrating violent behavior (Ryan, 2003). Other 
critics claim (Kines, 2010) that television doesn't activate all of our senses since it only triggers sight and hearing and thus new and multisensory occurrences simply do not happen. "The brain is simply on autopilot and we find ourselves bored, hence we channel surf" (Ryan, 2003, p. 296). Nevertheless, a teacher should be able to mitigate concerns related to violence by using suitable programs. Moreover, according to Howard Gardner's Theory of Multiple Intelligences, every student learns differently and has different intelligences (Johnson, 2005) so one could argue that television might be one of many resources used to motivate some or many students within a classroom separated by diverse learning abilities.

\section{Subtitles and closed-captioned television}

Ovando also recognizes the importance of television subtitles as a compliment to the viewing process. "Subtitles are not only for the hearing impaired, but some EFL students have asserted that television subtitles are also a crucial part of the television program viewing process because they give students confirmation of English words or expressions otherwise not easily understood" (Ovando,2006, pp. 110-111). Some researchers affirm the significance of subtitles during the viewing process but conclude their reliance should be strongly discouraged over time as second-language confidence progresses (Katchen, 1992). In other research studies, (Bean \& Wilson, 1989; Goldman \& Goldman, 1988) students using captioned materials showed significant improvement in reading comprehension, listening comprehension, vocabulary acquisition, word recognition, decoding skills, and overall motivation to read (Parks, 1994). Carolyn Parks also recognized a study by Thomas Garza in 1991. Garza "used verbatim captioning with adult ESL learners and adult Russian learners to explore the language learning benefits of merging spoken and printed text into one medium. He chose short (2-4 minutes), verbatim captioned segments from actual Russian and American TV programs which provided a kind of visual glossary for difficult vocabulary. When, over time, he tested students' ability to use specific vocabulary from the segments in retelling of their content, he found significant increases in comprehension on the segments, as well as recall of the language used in them" (Parks, 1994, p. 3).

\section{Video technology inside of South Korean classrooms today}

As mentioned, there is evidence to suggest South Korean teachers are embracing English television programs within their classrooms (Kines, 2010). Additionally, The Joong- Ang Daily newspaper in South Korea reported other ways video technology has been incorporated into classrooms (Kim, 2010). As of July $16^{\text {th }}, 2010$, one-hundred and thirty-two public schools were using digital textbooks (Kim, 2010). "Digital textbooks are highly effective in developing interest in learning and improving study habits," said Kwon Seok-min, Chief of the Elearning section of South Korea's Ministry of Education, Science, and Technology (Kim, 2010). A student using digital textbooks stated she can remember things more easily by watching videos on the computer than by looking at pictures in regular textbooks (Kim, 2010). "The results have been positive. Last year, students at the school achieved ten points higher on average in subjects in which digital textbooks were used - Korean, social studies and science, than in other subjects. Exams that were given by the Korea Education \& Research Information Service showed similar results (Kim, 2010). Of course, digital textbooks employed for subjects outside of EFL differ from English television programs adopted in EFL classes, but students' motivation to engage both resources might be prompted by visual and audio factors typically not induced by traditional textbooks.

"Last September, in an attempt to eliminate Korea's reliance on private education, the Ministry of Education, Science, and Technology launched a project to install Internet Protocol Television Services (IPTV) (Kim, 2010). "IPTV helps to grab students' attention at the beginning of class," Chang Woo-Seok, a teacher at the school said (Kim, 2010). Mister Chang did indicate that more updates are necessary and that IPTV is primarily needed in the countryside where there are fewer private education institutes. Some may wonder how IPTV will combat Korea's reliance on private education if the technology is primarily delivered in remote areas distant from most well-known private-education institutes. "Meanwhile, IPTV providers such as KT, LG, and SK have been quick to create educational materials specifically for IPTV" (Kim, 2010). "More people are watching English education content" said Seo Jung-ryul, chief of KT Media. "We will continue to develop content that contains valuable information for English education" (Kim, 2010). 
In all, one could propose that TV, IPTV, and digital textbooks capture student interest based on a "meaningful-learning" element. Some proponents who specialize in educational psychology assert the best way to teach any subject is to develop lesson plans that are interesting, engaging, and meaningful to students' interests so that all students will be more likely to pay attention and eagerly do what is asked of them (Kines, 2010). "Part of this strategy calls for the teacher to emphasize active, rapidly-paced instruction with varied modes of presentation and frequent opportunities for student participation" (Slavin, 2003, p. 372). In making the presumption that employing English television programs into a classroom can make lesson plans interesting, engaging, and meaningful, research suggests these programs might be a viable partner for EFL education in South Korea. However, as elated to earlier, how English programs are used and the type of programs employed inside of EFL classrooms are crucial considerations. In addition, despite the Korean Ministry of Education's adoption of modern forms of video technology, is Korea's exam-driven environment too competitive to fully accommodate such a method within its classrooms?

\section{South Korea's exam-driven environment}

South Korea's exam-driven environment, which is deeply rooted in Confucian ideologies, may serve as a potential obstacle to routinely welcome English programs within its EFL classrooms. It could easily be argued that exam stress, which is especially relevant for third-year high-school students in South Korea and teachers alike, is too overwhelming to completely covet English programs as a viable partner.

Back in the 1980s, Korean industries developed rapidly so the demand for highly educated workers increased. As a result, the government doubled the number of students entering universities and colleges. Consequently, education became available to the general public which resulted in cut-throat competition to enter top-rated universities due to the fact that just getting a university degree became standard and more weight started to be placed on a university's name when it came to job procurement (Rhie, 2002). Given acceptance into a top-ranked university was and still is primarily tied to entrance exam scores, Korean parents tend to be fixated on them and pressure their children to achieve results, thus creating the infamous 'examination hell' environment (Rhie, 2002). Rhie (2002) further suggested that what Korean students learn from elementary school to high school would easily fit on one CD-Rom. "For twelve years, they cram their brains with this limited knowledge, which can hardly be classified as useful knowledge. Such 'knowledge' is only useful once in their lifetimes during the college entrance exam" (Rhie, 2002, p. 171). With all the stress associated with 'examination hell', one can only ponder whether or not English television programs could be efficiently factored into classroom instruction. Despite the fact that Korea's Ministry of Education has issued documents containing a provision which explicitly states that one of the purposes of EFL education should be to develop communicative competence in all four areas (Kim, 2001), teaching strategies tend to heavily favor reading comprehension and grammar techniques suited for university entrance exams. One the other hand, it could also be construed that the authentic nature that English television programs can deliver into a classroom ignite enough curiosity and interest among students to become more passionate about EFL learning.

\section{English video programs in Taiwan}

Johanna Katchen, who has taught in Taiwan for a number of years, has a lot of experience in utilizing English video programming as a tool for her EFL students. In addition, she has researched and suggested effective strategies of its use. Katchen asserts "Video programming provides an excellent tool for moving students from the artificially slow and clear English of teaching materials to the authentic English used by native English speakers" (Katchen, 1997, p. 1). Some research suggests that there are two distinct positive sides of watching English television programs. Watching English programs is enjoyable so it provides a catalyst to motivate EFL students to learn other important components such as pronunciation, vocabulary use, intonation and even habits of nativeEnglish speakers. Barring the enjoyment factor, Katchen dissuades EFL teachers from using English movies inside of the classroom since they are too long on time. Instead, she recommends situational comedies (sitcoms) because they are humorous, show cultural differences which can be discussed in class, and fit young people due to their light-hearted genre (Katchen, 1997). Katchen proclaimed that cable television programs have been successfully employed with university students in Taiwan but implied that a teacher may have to do more ground work in order for these programs to be successfully adopted in high schools. "Some people mistakenly believe that using video in 
the classroom means that the teacher can turn on a two-hour movie and take a rest. In reality, using video requires far more work from the teacher. High school teachers are very busy people and have much required material to teach. Video use has to be supplemented, but it can add freshness and excitement to a classroom" (Katchen, 1997, p. 2). Katchen suggests gradual implementation of situational comedies as a lesson-plan compliment.

\section{Short video clips and situational comedies}

Research seems to favor the use of short video clips and prediction exercises for EFL instruction. Ovando (2006) advises selecting short clips of one to five minutes, planning, previewing activities to prepare students for what they will see, experimenting with prediction and other critical analysis through silent viewing or sound only, and planning meaningful post viewing follow-up. Katchen (1997) stated "Our level of tolerance is much lower in a foreign language; we tend to be more satisfied with shorter bits we understand or are led to understand, and we feel a sense of achievement. Just one or two scenes in a class encourage students to watch the rest on their own time outside of class" (Katchen, 1997, p. 3). However, in South Korea, it could be predicated that there just is not enough time for high-school, and perhaps even middle-school students, to consistently watch enough English content outside of class to achieve desired results. Within class however, situational comedies are conducive since one program can be divided up into eight or so two-to-four-minute scenes. Katchen (1997) indicated that different activities can be introduced for each scene so repetition of each scene is a key factor so students can watch a scene, do an activity, watch it again to check work, and then see it a third time for review before moving to the next scene. An advantage that sitcoms have is that students can become familiar with each of the characters which can add an additional level of comfort for students. Finally, since Asian students tend to want to understand every single word and have a low tolerance for ambiguity, sitcoms present an opportunity for them to depend on their real-world knowledge to predict what they will see and hear (Katchen, 1997). An EFL teacher can further set-up a video lesson by advising students that they most likely will not be able understand everything in their first viewing and to get actively involved in the decoding process versus passive viewing. Consequently, if subtitles are used, "Students can be taught to find clues to meaning from the visual context and their own knowledge of the word" (Katchen, 1992, p. 6) so they can lessen their dependability on subtitles.

\section{Video technology and emotion}

Peter Serdyukov, a lesson planning specialist, believes the use of video technology inside of classrooms can enhance a student's emotional state. Video technology, to include TV, DVD, and video clips, is further listed as one of the five major groups of educational technology and can be used in all phases of lesson planning to expand opportunities for productive teaching and learning (Serdyukov, 2004). Also, "Video technology can affect the emotional state and cognitive processes of the learner since pictures, colored and moving, seem to catch our attention far better than plain text which can be supported by the dramatic spread of videos and video games" (Serdyukov, 2004, p. 44). Serdyukov (2004) also supports other researchers in that video technology brings reality and higher motivation into teaching and learning.

\section{News broadcasts and prior knowledge}

News broadcasts can also motivate students to learn English due to their authentic content and also because news broadcasts can offer additional visual aids for comprehension. News stories are typically short in nature so they fit in with time recommendations. News people can provide excellent role models for proper English since their pronunciation tends to be top notch and their grammar is superb. Katchen (1992) added that news writers seem to be sensitive to having foreign and non-native speaking listeners so they add extra visuals and print information at the bottom of the screen to facilitate understanding. An educator has to be careful to select appropriate newscasts to stimulate his or her class. For example, an American or British news story may not be appealing to EFL students in other countries unless the story is deemed worthy on an international basis, humorous to some level, or covering subject matter familiar with EFL students. It can be easily assumed that most people, including students, are mostly comfortable with subject matter they already know. As Katchen (1994) pointed out, "We English teachers are familiar with the jargon and ways of speaking of our profession, but if a nuclear physicist came to lecture us in the same way he would address his colleagues, we would be lost. Our problem would not necessarily be one of language, but one of context: we are simply not familiar with the concepts" (Katchen, 1994, p. 9). Additionally, 
whether a teacher employs a sitcom, newscast, or other style of video clip within a classroom, activating students' prior knowledge is key prior to viewing content. We can help EFL students bridge the gap about what is known versus not known about a subject by engaging their prior knowledge. When students are given opportunities to demonstrate what they already know about a subject, more control is given to students, making the teaching environment more student centered. "The results of the transfer encourage students to build on existing strengths to best comprehend new content and skills" (Serdyukov, 2004, p. 57). Charles Leyba concluded that effective instruction is student-centered because it gives students multiple opportunities to extend their understandings and apply their knowledge (Leyba, 2005). So, finding appropriate news content familiar with students in some way, shape, or form is an important component of the process. (Katchen, 1994) suggests some pre-teaching activities a teacher could include prior to viewing new content in a news story. She highlighted the importance of asking background questions such as who, what, where, and why? Also, Katchen indicated that reviewing complex and key vocabulary words is an essential pre-viewing process. Finally, pronunciation practice of names, previewing key vocabulary words and idiomatic expressions, or related countries can benefit the procedure as well.

\section{Comprehension handouts and cultural education}

In order to mitigate the potential for passive viewing, a teacher can provide handouts with multiple-choice, true/false, fill-in-the blank or other styles of questions to capture interest. Stempleski and Tomalin (1990) point out when students have to search for one bit of information, they tend to listen very attentively, whereas if they have no task at all, they may tend to listen more superficially (Katchen, 1992).

Another advantage of English programs is that they can offer cultural education typically not found in textbooks or audio tapes. (Tufts \& Tudor, 1990) noted that EFL students are less likely to see cultural cues than native speakers so it is important for a teacher to draw attention to cultural information relevant to understanding the content of the video (Katchen, 1997). As an example, Katchen (1997) eluded that a man dressed as a postman may easily be identified by a native speaker but not so easily by a student who has never encountered an American postman.

\section{Summary}

In summary, there are many details to consider when using English programs as a partner in an EFL classroom to include proper selection of programs, length, engaging prior knowledge, and providing appropriate handouts to avoid passive viewing. If done properly, research suggests that English programs, whether in the form of sitcoms, news broadcasts, or other, can be a valuable tool inside of an EFL classroom due to its ability to widely capture the attention and interest of EFL students.

\section{CHAPTER THREE: METHODOLOGY}

The purpose of this chapter is to present the quantitative methodology that will be used to answer research questions associated with this study. Numerical data will be gathered and analyzed to gauge whether English television programs can be a viable partner within South Korean EFL classes. After careful consideration of available research methods, I decided to employ a quantitative research study since it can be completed anonymously and administered to a large number of participants efficiently. Furthermore, this study may provide an explanation by way of generalizations and predictions.

\section{Setting and Population}

South Korea has a number of different institutions where students can study EFL. However, since the purpose of this study is to access the viability of English television programs as a partner inside of public-school classrooms in South Korea, only Korean EFL teachers who are currently employed within public schools with be invited to participate in this study. Elementary, middle, and high school EFL teachers will be targeted within the Gyeonggi-do province of South Korea due its large population base. 


\section{Treatment}

Individuals with contacts within South Korean public schools with help with this study. These individuals will welcome South-Korean public-school teachers to participate. Each teacher will be advised that he or she can take part in the study on an anonymous basis and that their participation will help us better understand the EFL teaching environment South Korea.

\section{Measuring Instrument: Survey}

The subjects of this study will be asked to fill out a short ten-question survey (Appendix A). As noted within Chapter Two, South Korean Public school teachers are very busy so a short survey is the best instrument to efficiently gain the participation of a larger target population. In addition, surveys are a familiar part of most peoples' lives in the sense that survey results are often cited in popular media, such as newspapers, magazines, and even television programs. Since the surveys will rely on each teacher's knowledge and attitude, the validity of the information is contingent on the honesty of the respondent. It could be presumed that some respondents may not provide honest answers due to a number of reasons.

\section{CHAPTER FOUR: FINDINGS AND ANALYSIS}

The participants in this study were South-Korean public-school EFL teachers within the Gyeonggi-do province of South Korea. More specifically, teachers from school districts in the cities of Seoul, Bucheon, Suwon and Incheon were asked to participate. In all, fifty surveys were collected from a combined base of elementary, middle, and high school EFL teachers.

\section{Purpose}

The purpose of this study is to review the viability of English television programs as a partner in South Korean EFL classrooms.

\section{Questions and Results}

1A. Are you a native Korean English teacher working at a public school in South Korea?
a) Yes
b) No
***If no, please do not fill out this form, thanks!***

Table 1.0

\begin{tabular}{|c|c|}
\hline Yes & No \\
\hline 50 & 0 \\
\hline
\end{tabular}

This first question above was a pre-qualifier to proceed with this survey. A "yes" answer was mandatory to proceed.

1B. If yes, what level of students do you teach?
a) Elementary School
b) Middle School
c) High School

Table 1B

\begin{tabular}{|c|c|c|}
\hline Elementary School & Middle School & High School \\
\hline 17 & 9 & 24 \\
\hline
\end{tabular}
population.

Fortunately, the participants work with different age groups so the study includes a satisfactory target 
2. How many years have you taught English at a public school?
a) 0 to 3 b) 4 to 7
c) 8 to 11
d) 12 to 15
e) 16 or more

Table 2.0

\begin{tabular}{|c|c|c|c|c|}
\hline $\mathbf{0 - 3}$ years & $\mathbf{4}$ to 7 years & $\mathbf{8}$ to 11 years & $\mathbf{1 2}$ to 15 years & 16 or more \\
\hline 23 & 9 & 5 & 8 & 5 \\
\hline
\end{tabular}

Fortunately again, the study includes respondents with a diversified experience range.

3. Have you ever instructed your students to watch any English television programs or movies inside your class as a part of a lesson plan?
a) Yes
b) No
***If no, you may skip questions 4 through 8 and proceed to question $\# 9 * * *$

Table 3.0

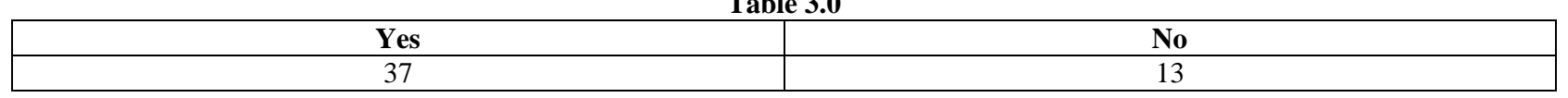

Table 3.0 illustrates that a majority of participants incorporate English television programs into their classrooms. Seventy-four percent in this case which is very close in percentage to a study I reported last year (Kines, 2010) in which approximately seventy percent of university students surveyed (425 participants) reported that their public-school teachers in high school coupled English television programs with lesson plans.

4. If yes, how many hours-per-month did your students view English television programs or movies as a part of your lesson plan?
a) 0 to 1 b) over 1 to 3
c) over 3 to 6
d) over 6 to 9
e) over 9

Table 4.0

\begin{tabular}{|c|c|c|c|c|}
\hline 0 to 1 & Over 1 to 3 & Over 3 to 6 & Over 6 to 9 & Over 9 \\
\hline 25 & 10 & 2 & 0 & 0 \\
\hline
\end{tabular}

It appears that a very small percentage of participants (2 of 37) use English programs somewhat routinely (3-6 hours-per-month). Table 4.0 may also elucidate that public school teachers in South Korea are too challenged with time constraints to consistently include English programs within lessons.

5. If you answered "yes" to question 3, why do or did you use English television programs or movies as a means to teach your students English?
a) It was required by my school admin.
c) other
b) I think it is a valuable method to teach

Table 5.0

\begin{tabular}{|c|c|c|}
\hline It was required by school administration & I think it is a valuable method to teach & Other \\
\hline 0 & 35 & 2 \\
\hline
\end{tabular}

Table 5.0 seemingly portrays that most respondents value English programs as a viable partner despite its inconsistent usage as represented by table 4.0. Table 5.0 may further signify that most public-school teachers are challenged with time constraints to routinely incorporate English television programs within classrooms. 
6. If you answered "yes" to question 3, were your English television programs or movies accompanied by Korean subtitles?
a) Yes
b) No

Table 6.0

\begin{tabular}{|c|c|}
\hline Yes & No \\
\hline 15 & 22 \\
\hline
\end{tabular}

Table 6.0 may indicate that most respondents potentially underscore the value of using subtitles. However, some researchers believe too much reliance on subtitles counters the purpose of using English programs in the first place as noted in my literature review. Perhaps, some may ponder how readily available English programs with Korean subtitles are within Korea's education industry.

7. If you answered "yes" to question 3, what other strategies do or did you use to compliment the viewing process within your classroom? **Please circle all that apply**
a) comprehension handouts
b) open discussion
c) pronunciation mimicking
d) role playing
e) other
f) none

Table 7.0

\begin{tabular}{|c|c|c|c|c|c|}
\hline Comp. Handouts & Open Discussion & Pronunciation & Role Playing & Other & None \\
\hline 21 & 9 & 7 & 7 & 6 & 2 \\
\hline
\end{tabular}

Table 7.0 favors comprehension handouts as compliment which can motivate students to take a more active role in the viewing process as suggested in Chapter Three. Six respondents indicated another strategy not listed in table 7.0, which may indicate a potential weakness in the question.

8. If you answered "yes" to question 3, do you think viewing English television programs or movies positively impacted the English speaking abilities of most of your students?
a) Yes
b) No
c) I don't know

Table 8.0

\begin{tabular}{|c|c|c|}
\hline Yes & No & I don't know \\
\hline 28 & 0 & 9 \\
\hline
\end{tabular}

Table 8.0 may demonstrate that most public-school teachers in South Korea who use English programs fully adopt its potential positive impact. Unfortunately, the survey does not specify how the strategy improved speaking skills. Since table 4.0 delineates that most participants (25 of 37) only employ English programs for one hour-per-month or less, some may infer that the programming interests students enough to continue the viewing process outside of their classrooms. The figures within table 8.0 appear to be a little surprising since gauging speaking-ability impact is very subjective and could be too difficult to ascertain, even within a full year of school. I expected more respondents to indicate that they did not know.

9. If you answered "No" to question 3, do you think that watching English television programs or movies could positively impact the English speaking abilities of most of your students?
a) Yes
b) No
c) I don't know

Table 9.0

\begin{tabular}{|c|c|c|}
\hline Yes & No & I don't know \\
\hline 9 & 4 & 0 \\
\hline
\end{tabular}


Some may only be able to speculate why most respondents to question number nine ( 9 of 13) believe that English television programs could positively impact the speaking abilities of most students, even though they do not integrate the strategy within their respective classrooms. Table 9.0 represents the thirteen participants who have never assimilated English programs within their classrooms. Again, this table may indicate that most teachers simply do not have enough time to fully, or even partially adopt the method.

\section{Summary}

One aim of the survey was to gain a better understanding of how EFL teachers in South Korea have incorporated English television programs into their lesson plans. In addition, the survey sought to solicit the participant's attitudes about the potential impact English television programs may have on their students. Most respondents (37 of 50) have assimilated English television programs within their classrooms and reported a favorable attitude towards the strategy. However, despite its perceived effectiveness, the majority of participants (25 of 37) also recorded minimal routine usage of English television programs of one hour or less per month.

Based on the survey results, we may postulate that public school teachers in Korea recognize value in using English television programs as a partner in their classrooms. However, most teachers who participated in this survey reported minimal usage of English programs (less than one hour-per-month) so there may be organizational or timeconstraint issues to routinely covet them as a viable partner. Furthermore, when correlating tables $1 \mathrm{~B}$ and 3.0, it might not be a surprise to understand that of the thirteen participants who have never used English programs within their classrooms, that nine work in public high schools were exam stress is significant. On the other hand, fifteen of the twenty-four high-school teachers who participated in the survey still found some time to adopt English television programs into their lessons. In addition, when associating table 2.0 with table 3.0, I observed there was an almost even split between teachers with eight or more years of experience compared those teachers with less than three years of experience of those who asserted they have never instructed their students to view English programs as a part of a lesson. Prior to initiating the survey, I incorrectly presumed that most respondents who had never incorporated English programming would be primarily teachers with eight or more years of experience under the assumption that these teachers were more likely to be too conservative to consider the strategy. But in contrast, ten out of eighteen teachers with more than eight years of teaching experience have used English programming within their classes. At any rate, a majority of participants surveyed seem to give credence to the use of English programs within public schools at all levels. The survey only included fifty respondents throughout four different cities within and just outside the Gyeonggi-do province of South Korea so some researchers may contend the study's participation pool is too small for complete representation.

\section{CHAPTER FIVE: SUMMARY AND RECOMMENDATIONS}

\section{Summary}

The purpose of this study was to review the viability of English television programs as a partner in South Korean EFL classrooms. A quantitative research study was enlisted to include fifty respondents throughout four different cities within and just outside the Gyeonggi-do province of South Korea. All respondents were EFL teachers who work at public schools. The aim of the survey was to gain a better understanding of how EFL teachers in South Korea have incorporated English television programs into their lesson plans. In addition, the survey sought to solicit the participant's attitudes about the potential impact English television programs may have on their students. Most respondents (37 of 50) have assimilated English television programs within their classrooms and reported a favorable attitude towards the strategy. However, despite its perceived effectiveness, the majority of participants (25 of 37) also stated minimal routine usage of English television programs of one hour or less per month. Furthermore, the study indicates EFL teachers at all levels (elementary, middle, and high school) are using English programs. Thirteen of fifty respondents had never instructed students to watch English programs as part of a lesson. Of those, nine participants were high school teachers were examination stress tends to be overwhelming.

The demand for English education in South Korea is extremely high as represented by household expenditures but English productivity has not matched investment levels so the Korean Ministry of Education is looking for avenues to eliminate Korea's reliance on private education. Currently, the Ministry of Education is advocating video technology as a lesson-plan compliment. 
Those who favor the usage of English television programs in and outside of the classroom cite its ability to stimulate critical thinking and create a meaningful learning environment which can positively affect the emotional state of EFL students. Those who are against using English television programs doubt its effectiveness and further blame television in general for violent behavior and reducing Scholastic Aptitude Test scores. To counter that argument, proponents of English television programs encourage teachers or even families to properly filter programming content and use comprehension handouts mitigate the potential for passive viewing.

Educators who have regularly applied English programming within EFL classrooms recommend short video clips to maintain student interest. Ideally, proponents suggests situational comedies and news broadcasts. Situational comedies offer humor while news broadcasts relevant to students can help make lesson plans meaningful. While some researchers foster the usage of subtitles in a student's native language to confirm complex expressions not easily understood, others believe the reliance of subtitles should be minimized as students increase their EFL skills. Given Korea's exam-driven environment may not leave enough time for educators to routinely embrace English programs as a partner inside of EFL classrooms, even minimal use may be enough to encourage students to continue the viewing process at home. Every student learns differently so using English programs within EFL classrooms could be one of many strategies used to engage diverse learning talents.

\section{Recommendations}

The study implies many public-school EFL teachers may not have enough time to routinely use English television programs as a lesson-plan compliment. However, it could be suggested that if the Korean Ministry of Education supports the concept, then teacher training for all public schools should be strongly considered so the programs are not solely used to give educators a break from teaching. While a majority of participants (37 of 50) in this study had included English programs into their lessons, it might be construed that those participants who have not used English programs might be missing out on an opportunity to provide a refreshing EFL lesson plan. All students learn differently so even minimal use of the strategy may be enough to inspire some EFL students to further embrace English television programs at home. The Korean Ministry of Education may want to originate its own independent study of the strategy. While doing so, perhaps a limited number of school districts within diverse regions of South Korea could be mandated to test the concept.

While this research study is quantitative, it does contain a subjective component to it. For example, out of the thirty-seven respondents who have used English programming, twenty-eight reported they believe the strategy positively impacted their students, leaving nine who did not now as highlighted in table 8.0. This begs a question for further research, how can those twenty-eight participants be sure their students were positively impacted? If an additional study were to be conducted, I would include a qualitative component to ascertain why those particular teachers responded that way. As a suggestion, these particular teachers could be invited for an open discussion so they can detail their experiences with incorporating English television programs. Lastly, it may be assumed that most respondents do not have enough time to routinely use English programming since twenty-five of thirty-seven participants reported minimal usage of one hour or less per month. However, an open discussion with these particular teachers as well could further strengthen this study and may potentially uncover other challenges these participants may have encountered with their lessons. In all, additional research should be considered.

\section{ACKNOWLEDGEMENTS}

This work was supported by Hankuk University of Foreign Studies Research Fund of 2011

\section{AUTHOR INFORMATION}

Scott Wayne Kines, has worked within the EFL industry in South Korea for over five years and is currently entering his third year as a general lecturer for the Practical English Department at Hankuk University of Foreign Studies in Yongin, South Korea. He fully strives to make English learning fun and meaningful. E-mail: Scott.kines@yahoo.com 


\section{REFERENCES}

1. Bean, R.M., \& Wilson, R.M. (1989). Using closed-captioned television to teach reading to adults. Reading Research Instruction, 28(4), 27-37.

2. Garza, T. (1991). Evaluating the use of captioned video materials in advanced foreign language learning. Foreign Language Annals, 24(3), 239-358.

3. Goldman, M., \& Goldman, S. (1988). Reading with closed captioned TV. Journal of Reading, 31(5), 458.

4. Johnson, J. (2005). Introduction to the Foundations of American Education. Thirteenth Edition. Boston: Pearson.

5. Katchen, Johanna E. (1992). World Service Television: ELT Resource for Asia. [Speech]. Retrieved October 1, 2010 from www.eric.ed.gov

6. Katchen, Johanna E. (1994). Learning to Listen to Authentic English from Satellite TV. [Speech]. Retrieved October 1, 2010 from www.eric.ed.gov

7. Katchen, Johanna E. (1997). Off-Air Video for High School English Classes: Some Considerations. [Speech]. Retrieved October 1, 2010 from www.eric.ed.gov

8. Kim, Ji-hyuk. (2010, July 16). Digital Education Takes Hold in Korean Classrooms. The Joong Ang Daily, Retrieved October 3, 2010 from http://joongangdaily.joins.com/article/view.asp?aid=2923237

9. Kim, Youngsang. (2001). Advanced Studies in EFL Teaching. Retrieved September 22, 2010 from www.eric.ed.gov

10. Kines, S. (2010). The Impact of English Television Programs on EFL Students in South Korea. HUFS International Journal of Foreign Studies, 2, 257-282.

11. Leyba, Charles F. (2005). Schooling and Language Minority Students: A Theoretical-Practical Framework. Los Angeles: LBD Publishers.

12. Ovando, Carlos J. (2006). Bilingual and ESL Classrooms. New York: McGraw-Hill.

13. Parks, Carolyn. (1994). Closed Captioned TV: A Resource for ESL Literacy Education. ERIC Digest, ED372662. Retrieved October 1, 2010 from www.eric.ed.gov

14. Rhie, Won-bok. (2002). Korea In Search of Country, The Society and the People Unmasked. Seoul: GimmYoung.

15. Ryan, Mark. (2003). Ask The Teacher, A Practitioner's Guide to Teaching and Learning in a Diverse Classroom. USA: Pearson Education.

16. Serdyukov, Peter. (2004). Effective Lesson Planning. Boston: Pearson Educational Company.

17. Slavin, Robert R. (2003). Educational Psychology, Theory and Practice, Seventh Edition. Boston: Allyn \& Bacon.

18. Tomalin, B. \& Stempleski, S. (1990). Video in Action. Prentice Hall International.

19. Tufts, R. \& Tudor, I. (1990). What the eye doesn't see: Cross-cultural problems in the comprehension of video material. Prentice Hall International.

20. Wigren, Harold E. (1962). Television and English Classes: Opportunities for Learning. The High School Journal, 45,(5), 214-217. Republished by the University of North Carolina Press. Retrieved September 21, 2010 from http://www.jstor/stable/40366770 